W SŁUŻBIE NIEDOSTOSOWANYM SPOŁECZNIE 



\section{W STRONĘ AKSJOLOGICZNEJ NEUTRALNOŚCI I PRÓB JEDNOZNACZNOŚCI. OD „WYKOLEJENIA” DO „ZABURZENIA”, CZYLI O PRZEMIANACH W KLUCZOWYCH DEFINICJACH PEDAGOGIKI RESOCJALIZACYJNEJ}

Towards an Axiological Neutrality and Unambiguity Tests. From 'Deviation' to 'Disorder', i.e. Changes in Key Definitions Rehabilitation Pedagogy

Summary: The purpose of the article is to attempt to synthetically present the changes in the use of the designates from the so-called group of descriptive terms in the literature: 'difficult individuals', i.e. synonyms and substitutes of 'social maladjustment' created on the grounds of Polish rehabilitation. It is an attempt to systematise knowledge around definitions that have grown into the language of pedagogy for the past seven decades.

The article shows the axiological and ambiguous dimension of these definitions, considers the issue of the value of a word as a transmitter saturated with something more than just a letter-sign. The need to break away from unnecessary value in definitions seems to be very important in 21 st century science. The advisability of organising the terms used is desirable and very necessary, especially for understanding the ideas and directions of development of the discipline. It is the concepts that allow for designing research and conducting diagnoses and descriptions. In this article the reader will be able to trace the changing definitions created by the elders of Polish rehabilitation and the ideas in which these definitions are rooted.

Ke y w ord s: axiology of concepts, elders of Polish rehabilitation, deviation, social maladjustment, behavioural disorders

1 Dr Barbara Ostafińska-Molik, pedagog, adiunkt w Instytucie Pedagogiki, Zakład Pedagogiki Zdrowia, Uniwersytet Jagielloński, ul. Batorego 12, 31-135 Kraków; e-mail: b.ostafinska-molik@ uj.edu.pl. 
Za pomocą słów określamy pojęcia, systematyzujemy to, czego dowiadujemy się o świecie. Słowa czasem są jednoznaczne, innym razem wieloznaczne. Pozwalają budować metafory przenoszące słuchacza lub czytelnika z jednego znaczenia na inne. Podobnie jak zaproponowany tytuł, który jest „sformułowany na tyle ogólnie", aby pobudzić wyobraźnię do tego, co czytelnik napotka dalej, i tym samym rozbudzić oczekiwania, które niekoniecznie pokryją się z intencją autora.

Bez wątpienia język odgrywa znaczącą rolę w opisie świata, w jakim funkcjonujemy. Pojęcia są podstawą języka nauki. Nauka zaś jest działalnością jednostek, które eksplikują, wyjaśniają i opisują rzeczywistość. Niektórzy badacze stają się prekursorami nowych zjawisk, dają impuls do wyjaśniania konkretnego problemu. Często na swojej drodze napotykają pasjonatów, którzy chcą włączyć się w rozwój danej dziedziny wiedzy, kontynuują i rozwijają ją - wynosząc na kolejny poziom, niejako dostrzegając/odkrywając „coś więcej” niż poprzednicy, poszerzając tym samym aparat pojęciowy danej dyscypliny. Nauka, podobnie jak życie, nie jest czymś stałym, jest procesem i nieustanną drogą poszukiwań. Kolejni naukowcy/odkrywcy dokładają swoją cegiełkę nowej wiedzy, a czasem jedne ustalenia zastępują drugimi. Jak trafnie zauważają Czesław Czapów i Stanisław Jedlewski, „nauka jest swoistym układem czynności kooperacyjnych, przebiegających na podstawie stałej ewolucji kulturowej wzorów postępowania [...]”2.

Wraz z rozwojem danej dyscypliny nauki, odkrywaniem nowych prawidłowości, pojęcia/definicje opisujące zjawiska są modyfikowane, precyzyjniej wyjaśniając wytworzone terminy. Dzięki nowym procedurom i rozwojowi metodologii pojęcia optymalizują się i doskonalą. Słowa opisujące rzeczywistość pozwalają, aby stała się ona bardziej wyrazista, zrozumiała i jednoznacznie interpretowalna.

Język tworzony w przestrzeni czasowej zmienia się, ewoluuje i podąża wraz $\mathrm{z}$ rozwojem kultury danego społeczeństwa. Jest mocno połączony zarówno z przeszłością, jak i teraźniejszością, a trzeba podkreślić, że historia:

[...] nie jest niepotrzebną opowieścią o minionym czasie ani raz na zawsze zamkniętą kwestią, lecz czymś, co nieustannie oddziałuje na teraźniejszość. Dlatego jeśli chcemy zrozumieć wydarzenia rozgrywające się przed naszymi oczami, powinniśmy zainteresować się historią. Patrząc z perspektywy historycznej, będziemy mieli szansę zrozumieć przyczyny tego, co jest. Nierzadko też spojrzenie w przeszłość potrafi dostarczyć impulsów do kształtowania przyszłości³

Dodatkowo musimy mieć też na uwadze, że doniesienia naukowe - koncepcje, nowe teorie, ustalenia - są zbiorowym wytworem licznej rzeszy naukowców posługujących się różnymi językami narodowymi. Stworzone przez nich pojęcia

2 Czesław Czapów, Stanisław Jedlewski, Pedagogika resocjalizacyjna (Warszawa: Państwowe Wydawnictwo Naukowe, 1971), 10.

3 Clemens Hillenbrand, Pedagogika zaburzeń zachowania (Gdańsk: Gdańskie Wydawnictwo Pedagogiczne, 2007), 34. 
następnie przenoszone są do języków rodzimych innych badaczy. Przyjrzyjmy się prostemu przykładowi. Grupa pojęć zapożyczanych do języka polskiego, a określających kwestie zaburzeń czy niedostosowania jest dość liczna, na przykład: conduct disorder, behaviour disorder, unsettled behaviour, maladjusted, delinquent behavior. Pojęcia te są różnie rozumiane już w oryginalnym języku - tu dla przykładu - angielskim 4 . Jeśli zatem różni badacze danej narodowości dokonają własnej interpretacji, to tym samym wprowadzają do świata nauki różne znaczenia słów czy zakresy pojęć definicyjnych. Inny problem, na jaki warto zwrócić uwagę w posługiwaniu się definicjami, związany jest z przekładem międzyjęzykowym „Z - na”. George Steiner, wybitny amerykański intelektualista, zwrócił uwagę, że: „każdy model komunikacji jest jednocześnie modelem translacji, wertykalnego lub horyzontalnego transferu znaczenia. Żadne dwie epoki historyczne, żadne dwie klasy społeczne, żadne dwie społeczności nie używają słów i składni dla oznaczenia dokładnie tych samych rzeczy, po to, by wysłać identyczne sygnały określonego wartościowania i wnioskowania"s.

Wśród interesujących nas terminów, które weszły w polskojęzyczny obieg naukowy, a wywodzą się z języka angielskiego, możemy wyszczególnić: zapożyczenia, które pozostały w postaci niezmienionej i zasilają grupę internacjonalizmów (np. behaviour), formy, które stopniowo podlegały adaptacji fonetycznej i gramatycznej (np. behawioralny) oraz terminy przełożone dosłownie lub przy pomocy transformacji przekładowych niosących ze sobą uogólnienie lub redukcję znaczenia, nierzadko substytucję semantyczną. Zapożyczenia i formy zaadaptowane poniekąd automatycznie rozpoznawalne są jako terminy pochodzenia obcego. Natomiast przekład dosłowny - ze względu na wysoką asymetrię semantyczną i konotacyjną języka angielskiego i polskiego - często oznacza niedokładność, nierzadko kontrowersyjność nowo wprowadzonego terminu, który w języku przekładu może wydawać się nienaturalny, może łączyć się skojarzeniowo z inną dyscypliną, przybierać nacechowanie negatywne, wreszcie - może spowodować nadanie nowego znaczenia istniejącemu już określeniu. Kwestia wdrożenia, zaakceptowania, a co za tym idzie - utwierdzenia użycia terminu w języku przekładu jest procesem naturalnym, długofalowym, zdeterminowanym częstotliwością i konsekwencją używania go przez specjalistów zarówno w komunikacji słownej, jak i w tekstach pisanych. Upowszechnienie terminu konstytuuje wprowadzenie go na stałe do słownika pojęć i jednocześnie pogłębia rozumienie danej dyscypliny.

${ }^{4}$ Tłumaczone przykładowo jako: zaburzenia zachowania, zaburzenia postępowania, zaburzenia kontroli zachowania, niepokojące zachowania, niedostosowanie społeczne, zachowania przestępcze.

${ }^{5}$ George Steiner, „Rozumienie jako przekład”. W: Po wieży Babel. Problemy języka i przekładu (Kraków: Universitas, 2000), 84. 
Widzimy więc, jak złożoną materią jest język definicji czy zakresów pojęć. Po tym wstępie przejdźmy do rozważań dotyczących konkretnych już pojęć używanych na gruncie pedagogiki.

Myśląc o definicjach naukowych, nie sposób oderwać ich od idei, jakie krzewiły się na świecie. Idee te były inspiracją do tworzenia własnych pojęć na gruncie rodzimej pedagogiki. Spróbujmy je pokrótce prześledzić. Rolf Göppel w swoich badaniach nad historią idei dotyczącą zaburzeń zachowania wyodrębnił trzy istotne określenia definiujące ten obszar:

(1) „osoby moralnie zwyrodniałe” - od początku XIX wieku do 1879 roku;

(2) „jednostki psychopatyczne” - od 1880 roku;

(3) „zaburzenia zachowania” - od 1950 roku.

Początkowo zaburzenia wiązano z moralnością, następnie z chorobą, a w kolejnym wieku z konkretnymi teoriami i koncepcjami naukowymi.

Pierwszy etap rozwoju myśli idei „zaburzeń postępowania” był mocno połączony z obyczajowością i moralnością. Podwaliny pod taki tok myślenia dał Johann Heinrich Pestalozzi - „wychowanie do moralności powinno stanowić podstawę każdego oddziaływania wychowawczego". Według przywołanego autora dzieci z zaburzeniami zachowania są zepsute i zaniedbane w kwestiach moralnych. Wyróżnił on trzy źródła zaniedbania: przyczyny mające swe źródło w naturze, w społeczeństwie i dziecku jako wolnej osobie. Zjawisko degeneracji moralnej można było rozpatrywać w trzech wymiarach antropologicznych ${ }^{6}$.

Drugi etap rozwoju myśli idei „zaburzeń zachowania” był zakorzeniony w wadliwym funkcjonowaniu psychiki dziecka, nieprawidłowej strukturze systemu nerwowego i mózgu.

$\mathrm{Z}$ upływem czasu zaburzenia zachowania zaczęto łączyć z teoriami naukowymi. Początkowo mocno wiązano je $\mathrm{z}$ teoriami uczenia się i behawioryzmu. Według nich zaburzenia były wyuczone, co sugerowało, że można się ich oduczyć. Proces resocjalizacyjny miał więc za zadanie kształtować pożądane zmiany w zachowaniach indywidualnych i społecznych. Obecnie w literaturze przedmiotu obowiązuje różnorodność teorii i koncepcji przyczyn występowania trudności związanych z zachowaniem. Badacze nieustannie poszukują źródeł zaburzeń, ale poszukiwanie jednego modelu owych przyczyn może być bezzasadne, gdyż omawiane zjawisko jest na tyle zróżnicowane, że opracowanie jednego takiego modelu teoretycznego wydaje się niemożliwe. Źródeł nieprawidłowego funkcjonowania upatruje się między innymi w zaniedbaniach wczesnego dzieciństwa (braku zaspokojonych potrzeb), nieprawidłowych relacjach rodzinnych, błędach wychowawczych, nieprawidłowej strukturze rodziny, uszkodzeniach układu nerwowego, obciążeniach genetycznych, przeżytych traumach, zaburzeniach psychicznych, zaburzeniach osobowości itd.

6 Hillenbrand, Pedagogika zaburzeń zachowania, 42-43. 
W pedagogice czy też innych naukach pokrewnych badacze dążyli do konstruowania pojęć (charakterystycznych dla swojej dziedziny) jak najlepiej opisujących otaczającą ich rzeczywistość. Zobaczmy jednak, jak bardzo jest to złożone i trudne zadanie, odwołując się do przykładów konkretnych osób i ich sposobów pojmowania świata. Należy nadmienić, że ramy niniejszego artykułu celowo zostały ograniczone tylko do wybranych autorów, którzy tworzyli podwaliny polskiej resocjalizacji. Celem pracy jest bowiem zwrócenie uwagi na problem aksjologii języka i zmian, jakie zachodzą w próbach jednoznacznego definiowania.

Pierwsze nazwisko, które otworzy moją dyskusję o kluczowych definicjach pedagogiki resocjalizacyjnej, jest nieprzypadkowe. Zostało ono wprowadzone na listę najwybitniejszych kobiet w psychologii XX wieku przez redaktorów Sibylle Volkmann i Helmuta E. Lücka ${ }^{7}$. Mowa o Marii Grzegorzewskiej. Ta uczona $\mathrm{z}$ ogromną starannością zaangażowała się $\mathrm{w}$ analizę i tworzenie terminologii. Działania takie były niezwykle pożądane przy ówczesnym poziomie rozwoju polskiej psychologii i pedagogiki.

Maria Grzegorzewska uznawana jest za osobę, która wprowadziła do polskiej literatury pedagogicznej termin „niedostosowanie społeczne”. Zachodnim odpowiednikiem na tamte czasy było anglojęzyczne słowo: maladjusted. Pod nazwą młodzieży niedostosowanej Grzegorzewska rozumiała:

[...] zespół wszystkich nieletnich wymagających specjalnych metod wychowawczych, społecznych, medyko-psychologicznych i medycznych; [...] tych wszystkich, wobec których z jednej strony pracodawca i urzędy publiczne muszą stosować metody specjalne, z drugiej strony zaś wychowawcy muszą się uciekać do sposobów specjalnych; tych wszystkich, dla których trzeba czegoś więcej albo czegoś innego niż dla zespołu innych; tych wszystkich, którzy, jeśli się respektuje zasadę „równości”, potrzebują czegoś więcej niż „równości”, żeby osiągnąć poziom swoich „rówieśników”".

Nakreśliła ona też granice rozumianego przez siebie niedostosowania. „Skala dziecięctwa i młodości niedostosowanej rozciąga się od sieroctwa lub bezdomności aż do przestępczości, przechodząc przez klasyfikacje takie, jak »trudny «, »upośledzony«, "anormalny«, "zagrożony moralnie«, aż do "przestępcy»"10. Należy zaznaczyć, że słowa, które sformułowała, miały swoje odzwierciedlenie w silnym kontekście historycznym. Oto Polska po trudnych latach, pomimo pokoju, nadal zmagała się z traumą i negatywnymi skutkami II wojny światowej, dużą liczbą sierot, kalek, biedą, problemami mieszkaniowymi itd. Naukowcy próbują z licznych problemów, jakie wygenerowała sytuacja wojny, uporządkować otaczającą

7 Sibylle Volkmann-Raue, Helmut E. Lück, Najwybitniejsze kobiety w psychologii XX wieku (Gdańsk: Wydawnictwo GWP, 2015).

${ }^{8}$ Otton Lipkowski, Resocjalizacja (Warszawa: Wydawnictwa Szkolne i Pedagogiczne, 1987).

${ }^{9}$ Maria Grzegorzewska, Wybór pism (Warszawa: Państwowe Wydawnictwo Naukowe, 1964), 316-317.

10 Tamże, 317. 
rzeczywistość i opisać pewne zjawiska w ramach pojęciowych. A co ważne podkreślenia - wojna jest czynnikiem szczególnie sprzyjającym rozwojowi przestępczości. W badaniach cytowanych przez Kazimierza Pospiszyla i Ewę Żabczyńską stwierdzono silną zależność między stopniem rozwoju ekonomicznego a rozwojem przestępczości nieletnich ${ }^{11}$. Zatem polscy intelektualiści mieli przed sobą sporo naukowych wyzwań. Jak dalej pisze Maria Grzegorzewska:

Młodzież niedostosowaną społecznie, specjalnie grupę młodzieży moralnie zaniedbanej, tzn. wykolejonej wskutek przyczyn natury zewnętrznej - cechują tendencje społecznie negatywne. Zawsze i wszędzie "najgorsi” czują się na marginesie życia społecznego, nikomu niepotrzebni i przez nikogo nielubiani. Wyosobnieni z grupy, bez poczucia bezpieczeństwa, czują krzywdzącą ich „inność”. Przez porównanie z innymi czują różnokierunkowe zahamowania i utrudnienia, przeżycia frustracyjne się pogłębiają i powodują coraz większe zmiany charakterologiczne (niezrealizowane potrzeby intelektualne i moralne, np. upokarzający wpływ opóźnienia szkolnego, poczucie, że drogi życia dostępne innym, są dla nich zamknięte itp. ${ }^{12}$.

Pomimo słabego jak na tamte czasy aparatu badawczego naukowcy dostrzegali różne przyczyny powodujące trudności w funkcjonowaniu społecznym. Badaczka postawiła w swojej definicji silny akcent na osobowościowe wyznaczniki niedostosowania. Jak zobaczymy dalej, wielu badaczy pójdzie jej śladem.

W tym samym okresie tworzyła i publikowała Natalia Han-Ilgiewicz. Jednostki niedostosowane społecznie zakwalifikowała według czterech istotnych kryteriów: (1) niedostosowanie do warunków, (2) do ludzi, (3) do norm, (4) do obyczajów. Jej rozumienie niedostosowania społecznego jest niezwykle szerokie. Zwraca ona uwagę na opóźnienia emocjonalne, infantylność, impulsywność. Uznaje, że jednostki niedostosowane „stosują środki naiwne, często nieodpowiadające ich faktycznemu rozwojowi”, a w działaniach takich osób przeważa impulsywność nad racjonalizmem ${ }^{13}$.

To dość szeroko rozumiane niedostosowanie społeczne przez kolejnych badaczy było zawężane. Poszukiwano lepszego desygnatu, który doprecyzuje zakres problemu. Mianowicie w literaturze przedmiotu pojawia się pojęcie „wykolejenie”. Spotkamy je przede wszystkim w pracach Czesława Czapowa i Stanisława Jedlewskiego - aczkolwiek nie jest ono pojęciem nader eksponowanym przez przywołanych badaczy. Pojęciu wykolejenia dużo uwagi poświęca Stanisław Górski. Swoją książkę Metodyka resocjalizacji podzielił na trzy zasadnicze rozdziały: wykolejenie społeczne, resocjalizacja, profilaktyka, podkreślając tym znaczenie

11 Za: Kazimierz Pospiszyl, Ewa Żabczyńska, Psychologia dziecka niedostosowanego społecznie (Warszawa: Państwowe Wydawnictwo Naukowe, 1985), 114.

12 Grzegorzewska, Wybór pism, 350.

13 Natalia Han-Ilgiewicz, Dziecko $w$ konflikcie z prawem karnym (Warszawa: Państwowe Zakłady Wydawnictw Szkolnych, 1965). 
używanych w latach 80 . XX wieku definicji ${ }^{14}$. Zatrzymajmy się na tej pracy. Jest ona o tyle istotna, że w tamtym okresie była ważnym kompendium dla praktyków, którzy jednocześnie byli promotorami definicji w niej zawartych. To, co jest warte głębszej refleksji, znajdujemy w rozdziale pierwszym, który opisuje podział i rozumienie podstawowych słów używanych w przestrzeni pedagogiki resocjalizacyjnej - czyli pojęć „niedostosowanie” i „wykolejenie społeczne”. Tu należy poczynić pewną uwagę, bo sam autor tego nie robi, ale praca Górskiego była silnie inspirowana twórczością Czapowa. Nazwisko to wprawdzie znajdziemy w książce Metodyka resocjalizacji, ale jest ono cytowane bardzo zdawkowo. Górski opisuje definicje i rozumienia pojęcia, dokonując analizy poszczególnych elementów wykolejenia, na które składają się niezgodne z normami zachowania jednostki, stan jej osobowości i przyczyny negatywnego postępowania. Mówiąc o pojęciu młodzieży trudnej, niedostosowanej, wykolejonej społecznie - zalicza do niej nieprzestrzegających norm prawnych nieletnich i młodocianych, "gitowców, gwałcicieli, włamywaczy, a także nie ściganych przez prawo, lecz naruszających etyczne i obyczajowe normy alkoholików, narkomanów, hipisów (dzieci-kwiaty), nie uczących się i niepracujących "urodzonych w niedzielę«, skłóconych z rodziną, szkołą i wszelkimi uznanymi autorytetami »indywidualistów « itd." ${ }^{15}$. Wymienione osoby zostały zakwalifikowane do jednej nadrzędnej kategorii. Współcześni badacze z łatwością dostrzegą fakt, że tak pojemna kategoria wraz z rozwojem nauki musiała ulec podziałowi - hipisi (dzieci kwiaty) dla licznych to kontestatorzy (np. Tadeusz Paleczny) ${ }^{16}$; nieuczący się i niepracujący - to bezrobotni, zaś „skłóceni z rodziną, szkołą i wszelkimi uznanymi autorytetami” - to zbuntowani (np. Anna Oleszkowicz) ${ }^{17}$.

W definicji Górskiego osoby niedostosowane to takie, które: (1) nie są zdolne (nie mogą); (2) nie są skłonne (nie chcą). W pierwszej grupie mieszczą się osoby, które nie są zdolne do prawidłowego odgrywania ról społecznych wskutek niepełnosprawności (głusi, niewidomi, kalecy, przewlekle chorzy, upośledzeni). W drugiej grupie znajdują się zaś osoby, które są negatywnie nastawione do odgrywania ról społecznych ${ }^{18}$.

Jeśli zatem jednostka jednostka wykazuje brak skłonności do przestrzegania norm i wartości społecznych, wtedy mowa jest o wykolejeniu społecznym. Z tym że - jak podkreśla - owo odgrywanie ról nacechowane jest antagonizmem

14 Stanisław Górski, Metodyka resocjalizacji (Warszawa: Instytut Wydawniczy Związków Zawodowych, 1985).

15 Tamże, 6.

16 Tadeusz Paleczny, Kontestacja: Formy buntu we współczesnym społeczeństwie (Kraków: Wydział Studiów Międzynarodowych i Politycznych Uniwersytetu Jagiellońskiego, 1997).

17 Anna Oleszkowicz, Bunt młodzieńczy: uwarunkowania, formy, skutki (Warszawa: Scholar, 2006).

18 Górski, Metodyka resocjalizacji. 
destruktywnym, który jest konsekwencją egoistycznych i partykularnych postaw jednostki.

Poniższy schemat obrazuje rozumienie pojęcia niedostosowania społecznego wraz z zakresem jego znaczeń:

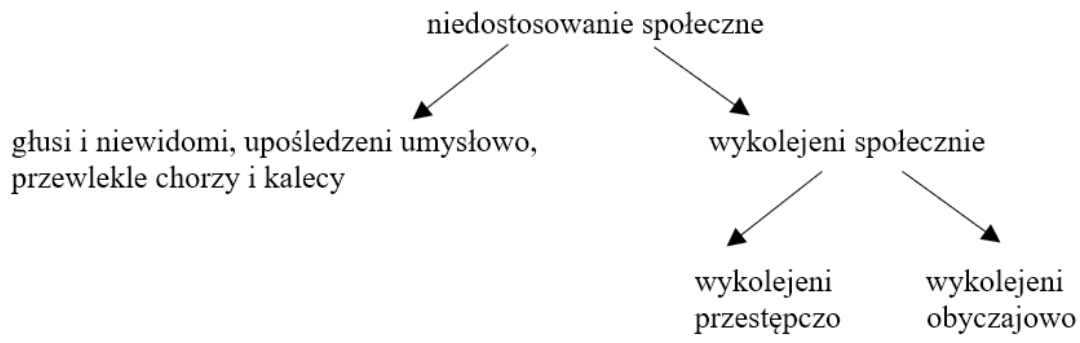

Źródło: Stanisław Górski, Metodyka resocjalizacji, 12.

Wraz z rozwojem dyscypliny osoby dotknięte niepełnosprawnością zostały wyłączone z pojęcia niedostosowania społecznego - aczkolwiek wielu naukowców, podając definicję niedostosowania społecznego, tę kategorię ludzi do niej dodawało. $\mathrm{W}$ ich przypadku niepełnosprawni zostali włączeni w kategorię wykluczenia społecznego. Obecnie dąży się do włączania tych osób do społeczeństwa. Wraz z rozwojem techniki i technologii osoby te mogą rekompensować swoje deficyty i dostosowywać się do społeczeństwa - uzupełniając swoje braki, potrafią bardzo dobrze radzić sobie w odgrywaniu ról społecznych (rodzinnych, zawodowych).

Czesław Czapów bardziej restrykcyjnie postawił granice między wychowaniem specjalnym, w którym mowa o niewidomych, głuchych, upośledzonych w zakresie narządu ruchu, upośledzonych umysłowo, przewlekle chorych, a wychowaniem resocjalizującym. Jednostka niedostosowana społecznie to nie jednostka o brakach psychicznych czy fizycznych, ale osoba, która wykazuje brak skłonności do respektowania systemu wartości i norm obowiązujących w społeczeństwie. Czapów definicję niedostosowania społecznego ukrył w wychowaniu resocjalizacyjnym, pisząc pośrednio, że niedostosowane społecznie są osoby odznaczające się mniej lub bardziej utrwalonym antagonistycznym stosunkiem do norm regulujących współżycie społeczne - ze względów asocjalnych lub ze względów dyssocjalnych ${ }^{19}$.

Jeśli chodzi o termin „wykolejenie społeczne” w rozumieniu Stanisława Górskiego, to jest on trójpoziomowym modelem, który składa się z: (1)

19 Czesław Czapów, Wychowanie resocjalizujące. Elementy metodyki i diagnostyki (Warszawa: Państwowe Wydawnictwo Naukowe, 1978), 41. 
przejawów (antagonistyczno-destruktywne zachowania); (2) stanu osobowości; (3) przyczyn (czynników) ${ }^{20}$.

W historycznej literaturze przedmiotu spotkamy również „uszczegółowienia wykolejenia”. Czapów pisze o: wykolejeniu złodziejskim - obejmującym kradzieże czy kradzieże z włamaniem, wykolejeniu seksualnym - erotomanii ${ }^{21}$. Górski wspomina o wykolejeniu przestępczym, czyli o łamaniu norm prawnych, oraz o wykolejeniu obyczajowym, czyli o łamaniu norm moralnych i obyczajowych. Wprowadza też termin wykolejenie obyczajowo-przestępcze - mając na myśli jednostki, które jednocześnie łamią normy obyczajowe i prawne - aczkolwiek to pojęcie również pojawiło się już w pracy Czapowa z 1978 roku $^{22}$.

Przywołanie tylko tych dwóch autorów pokazuje, jak ważne było dla nich zamykanie pewnych zjawisk w ściśle określonych kategoriach. Można zauważyć, że w wykolejeniu przestępczym mieści się wykolejenie złodziejskie - w obu mowa o łamaniu prawa. Należy postawić pytanie, dlaczego autorzy wprowadzili do literatury takie rozróżnienia. Zapewne Górski próbował zamknąć wykolejenie (w kontekście łamania norm) w szerszych ramach, dostrzegając potrzebę odniesienia się do przepisów prawa - w których były zapisane listy przestępstw (bójki, kradzieże, gwałty, pobicia śmiertelne, zabójstwa itd.), zaś Czapów zwrócił uwage na kategorię wykolejenia pod względem najbardziej popularnej kategorii przestępstw, uznając, że należy ją wyodrębnić jako samodzielne twierdzenie (definicję). Chociaż Górski nie powołuje się na Czapowa, to jednak ten już w 1978 roku posłużył się określeniami „wykolejenie przestępcze” i „wykolejenie obyczajowe”. Te dwie definicje są dla niego kategoriami podrzędnymi. Spina je bowiem właśnie wykolejenie społeczne. „Wykolejenie przestępcze polega na łamaniu norm prawnych, natomiast wykolejenie obyczajowe - na łamaniu norm obyczajowych"23.

Dość hermetyczny język Wychowania resocjalizującego tego autora był zapewne inspiracją dla Stanisława Górskiego, który swoją książkę chciał w większym stopniu zaadresować do praktyków. Jak pisze Jan Konopnicki, „praca Czapowa to niejednokrotnie pogranicze literatury pięknej z rozprawą pedagogiczną"24. Taka krytyka wynikała z braku szerszego rozwinięcia ustaleń empirycznych w konkretne wskazówki dla praktyków-specjalistów.

Czesław Czapów używał też dość wartościującego języka, pisząc o osobach wykolejonych. Wymieniał, że są to osoby uprawiające:

- przestępczość złodziejską (np. kradzieże, wyłudzenia);

- przestępczość bandycką (rozbój, przestępstwa przeciwko życiu i zdrowiu);

- przestępczość zabawową (wandalizm, uszkodzenie cudzego mienia);

20 Górski, Metodyka resocjalizacji, 13.

${ }^{21}$ Czapów, Wychowanie resocjalizujące..., 99.

22 Tamże.

23 Tamże, 111.

${ }^{24}$ Jan Konopnicki, Niedostosowanie społeczne (Warszawa: Państwowe Wydawnictwo Naukowe, 1971). 
a także odznaczające się:

- zachowaniami autodestrukcyjnymi (alkoholizm, narkomania);

- wykolejeniem seksualnym (przedwczesne rozpoczęcie współżycia seksualnego, prostytucja);

- pasożytnictwem społecznym (młodzież, która się nie uczy i nie pracuje).

Patrząc na pojęcia użyte przez nestora polskiej resocjalizacji, widzimy, że mają one dla współczesnego odbiorcy już tylko historyczny wydźwięk. W pojęciach tych możemy dostrzec ewolutywną funkcję języka. Z biegiem czasu słowa zaczynają bowiem nabierać innego kontekstu znaczeń.

Kolejne istotne nazwisko, które chciałam wprowadzić do dyskusji, to Otton Lipkowski. Swoją pracę Resocjalizacja rozpoczyna od wprowadzenia czytelnika w termin „dostosowanie” i „niedostosowanie”. Również i on dostrzega wielość pojęć - używanych jako synonimy. Jak sam podkreśla, „W naszym kraju używane są różne określenia zamiennie, np. dziecko zdemoralizowane, wykolejone, moralnie zaniedbane, z zaburzeniami w zachowaniu się"25. Wspomniany autor w początkach lat 80. w następujących słowach określił społeczne niedostosowanie: ,jest to zaburzenie charakterologiczne o niejednolitych objawach spowodowane niekorzystnymi zewnętrznymi lub wewnętrznymi warunkami rozwoju, a wyrażające się wzmożonymi i długotrwałymi trudnościami w dostosowaniu do normalnych warunków społecznych i w realizacji zadań życiowych danej jednostki"26. Badacz ten upatrywał przyczyn niedostosowania polietiologicznie - czyli w aspekcie psychologicznym, socjologicznym i biologicznym.

Warto zwrócić uwagę na jeszcze jeden aspekt - porównanie słów: „niedostosowanie" i „nieprzystosowanie”, odnosząc się do ich znaczeń w słowniku wyrazów bliskoznacznych. Termin „przystosowanie” wywodzi się z wpływu koncepcji behawioralnych, z czasem rozszerzono go o określenie „społeczne”. Na kontinuum definicji przystosowania pojawia się „złe przystosowanie”. Liczne wyjaśnienia tych pojęć pojawiły się głównie na gruncie literatury amerykańskiej. Określenie „złe przystosowanie” tłumaczono na różne języki jako „nieprzystosowanie” lub „niedostosowanie"27.

Kazimierz Pospiszyl i Ewa Żabczyńska zwracają uwagę na jeszcze jeden wymiar nieścisłości terminologicznej. Otóż pod względem logicznym „niedostosowania na dobrą sprawę nie ma i nie może być. Samo życie bowiem pośród ludzi, wchodzenie w określone interakcje $\mathrm{z}$ nimi, jest określoną formą "dostosowania «”28. Tak więc autorzy zwrócili uwagę na problem wartości, jakie odnoszą się do słowa „niedostosowanie”. Jeśli pozbawione byłoby ono tego kontekstu (wartości społecznych), to niedostosowania nie ma - bo człowiek dostosuje się do każdej

\footnotetext{
25 Lipkowski, Resocjalizacja, 25.

26 Tamże, 30.

27 Pospiszyl, Żabczyńska, Psychologia dziecka niedostosowanego...

28 Tamże, 13.
} 
sytuacji według uznanego przez siebie sposobu widzenia świata. Przykładowo dostosowując się do potrzeby podtrzymania funkcji życia, taka jednostka uzna, że można zabierać jedzenie ze sklepu, nie płacąc za nie.

Inaczej opisuje termin „dostosowanie” Otton Lipkowski. Charakteryzuje go jako element wartościujący pozytywnie - „łatwe i dobre dostosowanie”. Dostosowanie jest rozumiane przez niego jako zachowanie się jednostki zgodne z przyjętymi normami społecznymi, zaś przystosowywanie się jednostek do „subkultur [...] gangu wykolejeńców” określa pojęciem „adaptacji” ${ }^{29}$.

Przywołani wcześniej autorzy byli promotorami przyjęcia szerokiej wersji terminu niedostosowania społecznego, czyli „wszelkich form wadliwego stosunku do innych ludzi wywołanych z różnego rodzaju zaburzeń emocjonalnych oraz defektów w tym zakresie" ${ }^{30}$. Tak szerokie granice powodowały, iż autorzy ci uznali, że termin „niedostosowanie społeczne” można stosować zamiennie z: „zaburzeniami w zachowaniu”, „patologią zachowania”, „zachowaniem dewiacyjnym”. Dla nich „owe terminy znaczą to samo" ${ }^{31}$. Czytając prace Kazimierza Pospiszyla z lat 70. i 80. ubiegłego stulecia, można dojść do wniosku, że badacz ten „niedostosowanie” wyjaśniał i operacjonalizował za pomocą kategorii psychiatrycznych i psychologicznych, a dokładnie zaburzeń psychicznych czy zaburzeń osobowości $^{32}$. Tak rozumiane niedostosowanie społeczne $\mathrm{z}$ jednej strony jest konkretnym zjawiskiem, a z drugiej procesem, którego krańcową formą jest przestępczość33. Tak pojmowany proces demoralizacji ma swoje konsekwencje $\mathrm{w}$ rozwiązaniach ustawodawczych, do czego jeszcze wrócę w dalszej części artykułu.

Od połowy XX wieku w literaturze pedagogicznej zaczął się pojawiać termin „zaburzenie zachowania”. W 1957 roku Jan Konopnicki opublikował pracę, używając właśnie tego pojęcia w tytule swojej książki Zaburzenia $w$ zachowaniu $i$ środowisko. W pracy tej zostały przedstawione doświadczenia autora, których nabył w zorganizowanej przez siebie w 1948 roku wrocławskiej świetlicy eksperymentalnej dla dzieci „trudnych”.

Sam Konopnicki zauważył, „że na pewnym etapie rozwoju [nauk pedagogicznych -B.O.-M.] pojawiła się konieczność porozumienia się co do treści pojęć powszechnie już przedtem używanych" ${ }^{34}$ i słusznie prognozował, że „niejeden element treści dzisiaj ustalonej zostanie z czasem usunięty" ${ }^{35}$. Zarówno Jan Konopnicki, jak i Halina Spionek do swoich tekstów wprowadzili pojęcie

29 Lipkowski, Resocjalizacja, 22-23.

30 Pospiszyl, Żabczyńska, Psychologia dziecka niedostosowanego..., 15.

31 Tamże.

32 Kazimierz Pospiszyl, Psychologiczna analiza wadliwych postaw społecznych młodzieży (Warszawa: Państwowe Wydawnictwo Naukowe, 1973); Pospiszyl, Żabczyńska, Psychologia dziecka niedostosowanego...

33 Tamże.

34 Konopnicki, Niedostosowanie społeczne, 13.

35 Tamże. 
„zaburzenie”. Oboje łączyli termin zaburzeń z niepowodzeniami szkolnymi. Ze względu na ramy niniejszego artkułu wątek ten nie będzie dalej rozwijany. Konopnicki mocno optował za jednoznacznością pojęć. W swojej książce Niedostosowanie społeczne pisze: „czas już najwyższy próbować treść tego pojęcia [niedostosowanie społeczne - B.O.-M.] ustalić, ponieważ szkody społeczne, jakie z braku precyzji pojęć w tej dziedzinie wynikają, mogą być nie do naprawienia" ${ }^{36}$. Halina Spionek również zauważyła, że termin „zaburzenia zachowania” „używany jest $\mathrm{w}$ literaturze $\mathrm{w}$ bardzo różnych zakresach oraz różnych odcieniach znaczeniowych" ${ }^{37}$. Zwróciła przy tym uwagę, że zaburzenia zachowania mają różną genealogię. Autorka termin ten odnosi do wszystkich jednostek (zarówno zdrowych, jak i chorych), „których zachowanie w sytuacjach społecznych niekorzystnie odbiega od przeciętnego obrazu charakterystycznego dla danego wieku" ${ }^{38}$. Termin „niedostosowanie społeczne” jest używany przez nią w znaczeniu wąskim albo szerokim. Szerokie rozumienie to takie, jakie przedstawia graf Górskiego wszystkie dzieci odchylone od normy. Obecnie takie rozumienie niedostosowania zostało wyeliminowane. Wąskie rozumienie definicji niedostosowania społecznego obejmuje jednostki, u których „zaburzeniu uległa sfera emocjonalno-wolowa oraz rozwój charakteru i osobowości, co powoduje częste zakłócenia stosunków społecznych między dziećmi a ich otoczeniem"39. Jeśli porównamy definicję Spionek z ujęciem Konopnickiego, to zauważymy spore podobieństwa w definiowaniu i charakteryzowaniu zjawiska niedostosowania społecznego.

Jak już była o tym mowa wcześniej, Jan Konopnicki dostrzegał ewolutywną formę języka, uznając, że pojęcia, którymi posługiwano się w latach 50. i 60. „moralnie zaniedbane”, „moralnie zagrożone” - wychodzą z użycia. Zastępowane są socjologiczną wersją tego pojęcia - „niedostosowanie” ${ }^{40}$. Kolejne istotne pojęcie to termin „wykolejenie”, zazwyczaj łączony ze słowem „przestępcze”. Połączenie to według Konopnickiego nie jest zbyt fortunne - bowiem dziecko wykolejone „mogło jeszcze nie mieć okazji popełnić przestępstwa”.

Autor ten na dłużej zatrzymuje się przy pojęciu „zaburzenie” - „zaburzenie emocjonalne" (lub „w zachowaniu się"), który to termin jest według niego bardzo zbliżony do „niedostosowania”, jednak z pewnym „ale”. W określeniu zaburzenie akcentowane są zmiany pod wpływem środowiska, w niedostosowaniu zaś - skutki tej zmiany (zarówno natury psychologicznej, jak i społecznej). Autor stawia jednak pewne granice w rozumieniu obu tych pojęć. Skutki niedostosowania są manifestacjami, „które tak samo nie są zaburzeniami, jak skutki zmiany

36 Tamże, 14.

37 Halina Spionek, Zaburzenia rozwoju uczniów a niepowodzenia szkolne (Warszawa: Państwowe Wydawnictwo Naukowe, 1975), 18.

38 Tamże.

39 Halina Spionek, Zaburzenia psychoruchowe rozwoju dziecka (Warszawa: Państwowe Wydawnictwo Naukowe, 1965), 276.

40 Konopnicki, Niedostosowanie społeczne, 25. 
w psychice nie są niedostosowaniem". W myśl tej idei zaburzenia zachowania mogą pomóc w odkryciu przyczyn niedostosowania jednostki.

Konopnicki, definiując zaburzenie, zwraca przede wszystkim uwagę na odchylenie od normy i na zmianę, jaka zachodzi w psychice jednostki. Przyczyna zaburzeń może tkwić zarówno w środowisku, jak i w dziecku. W podsumowaniu swoich rozważań w książce z 1971 roku Konopnicki stwierdził, „że spośród wielu pojęć, których dotychczas używano w naszym języku [...] najlepsze na pewno jest "niedostosowanie społeczne $" 41$.

Generalnie pojęcie zaburzenia mocno zakorzeniło się w definicjach psychiatrycznych. W literaturze pedagogicznej najczęściej termin „zaburzenia” był używany przez Halinę Spionek, Jana Konopnickiego i Bronisława Urbana. Można powiedzieć, że pojęcie „zaburzeń zachowania” promowali Konopnicki i zwłaszcza Urban. Urban był zwolennikiem używania tego pojęcia, ponieważ uważał, iż jest ono mniej stygmatyzujące niż „niedostosowanie społeczne”"

Termin „zaburzenie zachowania” obejmuje wiele kategorii i problemów. Jest to definicja „zbiorcza”. Ma silną konotację z tym, co rozumiemy pod pojęciem „norma”. Podobnie jak Konopnicki, Urban uważał, że zaburzenie poprzedza stan niedostosowania społecznego. Dodatkowo pisał: „zaburzenie emocjonalne przekształca się w zjawisko określone jako niedostosowanie społeczne [...] zaburzenie wyzwoliło niedostosowanie społeczne, a w miarę dalszego rozwoju staje się składową częścią problemu niedostosowania”" ${ }^{3}$.

Obecnie coraz częściej rozdziela się i stosuje pojęcia, takie jak na przykład: zaburzenia zachowania i emocji, zaburzenia opozycyjno-buntownicze itd. Wydaje się, że zabieg taki jest rozsądny. Z jednej strony jednostka może "cierpieć" na kilka dolegliwości jednocześnie - możemy używać jednego określenia na wiele zjawisk, wszystko, co odbiera zdrowie, można nazwać chorobą, ale pojawia się pytanie - czy pozwoli nam to na znalezienie najlepszej drogi leczenia i terapii?

Niewątpliwie życie wymaga budowania generalnych pojęć. Wynika to $\mathrm{z}$ faktu rozmaitości form zachowania. Warto zwrócić uwagę na jeszcze jedną kwestię. Należy pamiętać, że pojęcia używane w świecie nauki mają swoje przełożenie w funkcjonowaniu społecznym. Na przykład pojęcie „zaburzenia zachowania” mocno wrosło w grunt nauki o zdrowiu. Literatura psychiatryczna (Maria Orwid, Halina Sulestrowska, Tomasz Wolańczyk, Artur Kołakowski) ${ }^{44}$ wypełniona jest

${ }^{41} \quad$ Tamże, 28.

42 Bronisław Urban, Zaburzenia w zachowaniu i przestępczość młodzieży (Kraków: Wydawnictwo Uniwersytetu Jagiellońskiego, 2000), 18.

43 Tamże.

44 Maria Orwid, Kazimierz Pietruszewski, Psychiatria dzieci i młodzieży (Kraków: Collegium Medicum Uniwersytetu Jagiellońskiego, 1993); Tomasz Wolańczyk i in., Zaburzenia emocjonalne i behawioralne $u$ dzieci, red. Helena Baran-Furga (Warszawa: Wydawnictwo Lekarskie PZWL, 2015); Artur Kołakowski, Zaburzenia zachowania u dzieci: teoria i praktyka (Sopot: Gdańskie Wydawnictwo Psychologiczne, 2018). 
pojęciami zaburzeń zachowania / zaburzeń w zachowaniu. Diagnostyka, która korzysta z klasyfikacji DSM - IV czy obecnie V, przede wszystkim mówi o zaburzeniach zachowania. Z kolei ustawy, które regulują kwestie udzielania pomocy dzieciom i młodzieży, głównie korzystają z terminologii „niedostosowanie społeczne”. Spotkamy w nich zwłaszcza dwa pojęcia: „uczeń niedostosowany społecznie" i „uczeń zagrożony niedostosowaniem społecznym” ${ }^{45}$. Ustawodawca również nie stawia jednoznacznych granic pojęciowych - daje adresatowi norm szerokie pole do rozumienia - nigdzie w ustawie nie znajdziemy bowiem jednoznacznej definicji niedostosowania, tak samo jak nie znajdziemy jednoznacznych kryteriów w jego diagnozowaniu.

Czterdzieści lat temu Otton Lipkowski postawił pytanie: „Czy wobec trudności zdefiniowania pojęcia społecznego niedostosowania nie należałoby więc zaniechać usiłowań w kierunku ujednolicenia terminologii i uzgodnienia znaczeń terminologicznych?" ${ }^{46}$. Jego odpowiedź jest negatywna. Uważa, że porzucenie prób jednoznacznego definiowania nie jest wskazane, gdyż „uzgodnienie terminologiczne ułatwia porozumiewanie się i umożliwia zgodne postępowanie [...]. Ma to duże znaczenie w pedagogice, działaniach zespołów specjalistów: pedagogów, psychologów, psychiatrów i pracowników społecznych"47.

Obecnym promotorem definicji niedostosowania społecznego jest Lesław Pytka, który pisze:

Nieprzystosowanie wyraża się moim zdaniem w: a) nieadekwatnym funkcjonowaniu w rolach społecznych ważnych dla danego systemu społecznego b) przejawianiu postaw antagonistyczno-destruktywnych wobec istniejącego porządku prawnego, moralnego i obyczajowego c) nieumiejętności lub niechęci do zaspokajania potrzeb pierwszego i drugiego rzędu w sposób dopuszczalny i akceptowany społecznie ${ }^{48}$.

Analizując pojęcie niedostosowania społecznego przedstawione przez Pytkę, można zauważyć spory wpływ idei Stanisława Górskiego i inspirację jego myślą. Definicja współczesnego autora jest jednak bardziej rozbudowana i doprecyzowana.

45 Rozporządzenie Ministra Edukacji Narodowej z dnia 9 sierpnia 2017 r. w sprawie warunków organizowania kształcenia, wychowania i opieki dla dzieci i młodzieży niepełnosprawnych, niedostosowanych społecznie i zagrożonych niedostosowaniem społecznym (Dz.U. poz. 1578 z 2017 r. oraz poz. $1485 \mathrm{z} 2018 \mathrm{r}$.).

46 Lipkowski, Resocjalizacja, 27.

47 Tamże.

48 Lesław Pytka, „Narodziny i rozwój polskiej pedagogiki resocjalizacyjnej”, Student niepetnosprawny. Szkice i rozprawy 1, 8 (2008), 27. 
Nauka, jak twierdzą Czesław Czapów i Stanisław Jedlewski, ma opierać się na faktach i weryfikacji z danymi empirycznymi ${ }^{49}$. W momencie, kiedy dany problem nie posiada jednoznacznie zoperacjonalizowanej definicji, może pojawić się trudność z wyznaczeniem granic czy zakresu badań. Przywołani autorzy podkreślali przyporządkowywanie odpowiedzi wskaźnikom, które mają niepostrzegalne desygnaty i tym samym konstytuują rzeczywistość. Jeśli zatem definicja jest niejednoznacznie rozumiana, rozmyta - to może generować problemy związane ze zbieraniem odpowiednich danych, które mają weryfikować kreowane hipotezy. Należy też podkreślić, że język - słowo - są nośnikami wartości. Czym innym wydaje się język matematyki, gdyż przez swoje kody pozbawiony jest warstwy nacechowanej emocjami. Korzysta z logicznych symboli - znaków, które są podstawą komunikowania się z innymi. Czym innym jest zaś język słów jako przekaz definicji humanistycznych.

Aspekt aksjologiczny ma ważne znaczenie dla rozumienia używanych pojęć na gruncie pedagogicznym. Ucznia, który nieustannie pracuje nad jakimś zadaniem - możemy określić jako osobę upartą lub konsekwentną. Ktoś uparcie dąży do celu vs. konsekwentnie dąży do celu. Przyjęcie drugiego opisu pozwala odwrócić negatywną wartość słowa, która jako postawa konieczna w osiągnięciu celu (konsekwencja) jest $\mathrm{z}$ tego punktu widzenia $\mathrm{w}$ najwyższym stopniu pozytywna. Jeśli użyje się słowa „uparty” (np. uparty jak osioł), to będzie mieć ono wydźwięk negatywny. Negatywnie wartościowany jest świat stereotypu owego słowa, pozytywnie wartościowane jest marzenie i podążanie za nim. Jestem konsekwentny w moich wyborach, jestem przekonany, że są słuszne.

Za odrzuceniem słowa „wykolejenie" z języka resocjalizacyjnego przemawiać mogło silne negatywne nacechowanie leksemu, tym samym pojęcie to ma bardzo negatywny wydźwięk aksjologiczny. „Wykoleić" - to inaczej stracić panowanie, wykolejony to ten, który nie trzyma się w danych „ryzach”. W słowie „wykolejanie" jest sporo dramatyzmu. Jeśli bowiem dojdzie do wykolejenia, to pod wpływem dużej prędkości. Okazuje się, że najczęściej skutki są tragiczne. Pojazd wykolejony, który stracił kontrolę, rzadko nadaje się znów do transportu. Zazwyczaj ulega kasacji. Taka pejoratywna metafora dawałaby nikłe szanse na skuteczną resocjalizację i powrót do społeczeństwa.

Badacze wciąż się spierają o zakres i pojemność używanych definicji, ale w jednym są zgodni. Nie można używać słów wartościujących, zawierających ocenę cech charakteru czy osobowości - kategorie (określenia, opisy) mają rozdzielać zachowanie od osoby. „Jednostka $\mathbf{z}$ zaburzeniami zachowania”, „osoby $\mathbf{z}$ niepetnosprawnością". Posługiwanie się w taki sposób ową terminologią ma za zadanie chronić jednostkę przed negatywnym klasyfikowaniem i przypisywaniem

\footnotetext{
49 Czapów, Jedlewski, Pedagogika resocjalizacyjna.
} 
aksjologicznych znaczeń. Aczkolwiek nadal używa się pojęcia „jednostki niedostosowane społecznie”, a nie: ,jednostki $\mathbf{z}$ niedostosowaniem”. W tym układzie podkreśla się wymiar jednostki, która nie jest w stanie spełnić wymagań społeczeństwa. Można postawić może nader śmiałą tezę, że w tym przypadku wartość aksjologiczna oceniająca jednostkę stoi podrzędnie nad dobrem innych. Stąd pozbawienie owego opisywania jednostki przy zastosowaniu przyimka „z”.

$\mathrm{Na}$ istotny wymiar aksjologiczny pojęć zwrócił uwagę Czesław Czapów. Podkreślał, że pojęcia pedagogiczne polegają na porządkowaniu twierdzeń ze względu na przyjęty system wartości. Jak pisał dalej: „dla sformułowania twierdzeń pedagogicznych niezbędne są nie tylko zdania opisujące, ale i zdania wartościujące"50. Zdania wartościujące mają wyrażać określoną hierarchię obiektów i zdarzeń. Owo rozumienie wartości dotyczy rozumienia analityczno-normatywnego, wyrażając społeczne interesy i oczekiwania społeczne ${ }^{51}$. Jeśli zatem jednostka łamie daną normę, jej zachowaniu nadajemy interpretację w kategorii dobrze vs. źle.

Widzimy zatem, że na twierdzenie można patrzeć z dwóch wymiarów: wymiaru normatywnego - opisującego przejawiane zachowanie - lub z wymiaru wartości pojęcia, wartościującego osobę, która przejawia dane zachowanie.

W poniższej tabeli zestawiono próby poszukiwań komunikacji pojęciowej opartej na aksjologicznej neutralności.

Tabela 1. Komunikacja pojęciowa oparta na aksjologicznej neutralności

\begin{tabular}{|l|l|l|}
\hline \multicolumn{1}{|c|}{ Wymiar } & \multicolumn{1}{|c|}{ Ocena wartościująca } & \multicolumn{1}{|c|}{ Aksjologiczna neutralność } \\
\hline Oceny zachowania & $\begin{array}{l}\text { Jesteś zły } \\
\text { Jesteś niegrzeczny }\end{array}$ & $\begin{array}{l}\text { Źle się zachowujesz } \\
\text { Twoje zachowanie jest niepo- } \\
\text { prawne }\end{array}$ \\
\hline Słowa wartościującego & $\begin{array}{l}\text { Ułomny, kaleki } \\
\text { Wykolejony }\end{array}$ & $\begin{array}{l}\text { Osoba z niepełnosprawnością } \\
\text { Osoba z zaburzeniami w za- } \\
\text { chowaniu }\end{array}$ \\
\hline
\end{tabular}

Źródło: opracowanie własne.

Słowa łatwo potrafią stygmatyzować, a tym samym wpływać na samoocenę osób. Jednostka buduje w sobie przekonanie: jestem zły, jestem niedobry, jestem niegrzeczny, w konsekwencji niejednokrotnie poszukując potwierdzenia w swoich działaniach i ocenach. Nie radząc sobie z niską samooceną, podejmuje kolejne destruktywne czyny. Słowa wywołują konkretne odczucia „o" $\mathrm{i}$ „w” jednostce. Jeśli na przykład dana osoba kogoś uderzyła (pobiła) - to możemy określić ją następującymi sformułowaniami: łobuz, agresor, zwyrodnialec itp. Każde z tych

${ }^{50}$ Czapów, Wychowanie resocjalizujące..., 156.
51 Tamże. 
słów niesie ze sobą konkretny ładunek aksjologicznego wartościowania, zarówno dla samej jednostki, jak i dla osoby, która ją właśnie tak nazwała. Język jako wytwór człowieka pozwala konstruować obraz świata i siebie. Z punktu widzenia pedagogiki i edukacji problem ten jest nader ważny i niezwykle aktualny. Wydaje się zatem, że priorytetem jest jednorodność i neutralność definicji, słów, pojęć.

Jörge Schlee zwraca uwagę, że w nauce występuje „problem o charakterze podstawowym" ${ }^{25} \mathrm{w}$ kontekście tworzenia definicji. Mianowicie usunięcie z przestrzeni komunikacji jednego terminu i zastąpienie go innym. Bardzo trudno jest bowiem sprostać wymaganiom, jakie stawia się pojęciom naukowym, a zwłaszcza pojęciom empirycznym. Poza tym często założenia teoretyczne (ich różnorodność) powodują brak zgodności w przyjęciu jednej definicji zaburzeń w funkcjonowaniu. Dodatkowo - im bardziej coś jest ogólnikowe, ma szerszy zakres pojęciowy - tym więcej przypadków, kategorii może się zmieścić w takim pojęciu.

Można zatem zgodzić się ze stanowiskiem Clemensa Hillenbranda, że pewne określenia należą do dawnej epoki (między innymi: moralnie niedorozwinięte, zwyrodniałe, przestępcze, wykolejenie, trudne dzieci), inne pojawiają się czy też współistnieją w związku z określonymi koncepcjami naukowymi ${ }^{53}$. W świetle powyższego wydaje się, że pomimo prób wprowadzenia jednoznaczności i zawężania granic pojęć definicje używane na gruncie polskiej pedagogiki resocjalizacyjnej wymagają dalszego udoskonalania. Ponadto wskazane jest także zwracanie uwagi na konsekwencje związane z używaniem pojęć, które stygmatyzują i przyczyniają się do utrwalania wadliwych postaw i zachowań jednostki.

Streszczen i e: Celem artykułu są próby syntetycznego przedstawienia zmian w zakresie używania w literaturze desygnatów z tzw. grupy pojęć opisujących „trudne jednostki”, czyli synonimów i zamienników „niedostosowania społecznego” wytworzonych na gruncie polskiej resocjalizacji. Jest próbą usystematyzowania wiedzy wokół definicji, które od przeszło siedmiu dekad zdążyły wrosnąć w język pedagogiki.

Artykuł ukazuje aksjologiczny i niejednoznaczny wymiar tych definicji, rozważa kwestie wartości słowa jako przekaźnika nasyconego czymś więcej niż tylko znakiem-literą. Potrzeba oderwania się od zbędnego wartościowania w definicjach wydaje się nader istotna w nauce XXI wieku. Celowość uporządkowania używanych pojęć jest wskazana i nader potrzebna, zwłaszcza dla rozumienia idei i kierunków rozwoju dyscypliny. To właśnie pojęcia pozwalają na projektowanie badań, prowadzenie diagnoz i opisów. W niniejszym artykule czytelnik może prześledzić zmieniające się definicje tworzone przez nestorów polskiej resocjalizacji i idee, w których te definicje są zakorzenione.

Słowa kluczowe: aksjologia pojęć, nestorzy polskiej resocjalizacji, wykolejenie, niedostosowanie społeczne, zaburzenia w zachowaniu

52 Za: Hillenbrand, Pedagogika zaburzeń zachowania.

53 Tamże. 


\section{Bibliografia}

Czapów, Czesław. Wychowanie resocjalizujace. Elementy metodyki i diagnostyki. Warszawa: Państwowe Wydawnictwo Naukowe, 1978.

Czapów, Czesław, Jedlewski, Stanisław. Pedagogika resocjalizacyjna. Warszawa: Państwowe Wydawnictwo Naukowe, 1971.

Górski, Stanisław. Metodyka resocjalizacji. Warszawa: Instytut Wydawniczy Związków Zawodowych, 1985.

Grzegorzewska, Maria. Wybór pism. Warszawa: Państwowe Wydawnictwo Naukowe, 1964.

Han-Ilgiewicz, Natalia. Dziecko w konflikcie z prawem karnym. Warszawa: Państwowe Zakłady Wydawnictw Szkolnych, 1965.

Hillenbrand, Clemens. Pedagogika zaburzeń zachowania. Gdańsk: Gdańskie Wydawnictwo Pedagogiczne, 2007.

Kołakowski, Artur. Zaburzenia zachowania u dzieci: teoria i praktyka. Sopot: Gdańskie Wydawnictwo Psychologiczne, 2018.

Konopnicki, Jan. Niedostosowanie społeczne. Warszawa: Państwowe Wydawnictwo Naukowe, 1971.

Lipkowski, Otton. Resocjalizacja. Warszawa: Wydawnictwa Szkolne i Pedagogiczne, 1987.

Oleszkowicz, Anna. Bunt młodzieńczy: uwarunkowania, formy, skutki. Warszawa: Scholar, 2006.

Orwid, Maria, Pietruszewski, Kazimierz. Psychiatria dzieci i młodzieży. Kraków: Collegium Medicum Uniwersytetu Jagiellońskiego, 1993.

Paleczny, Tadeusz. Kontestacja: Formy buntu we wspótczesnym społeczeństwie. Kraków: Wydział Studiów Międzynarodowych i Politycznych Uniwersytetu Jagiellońskiego, 1997.

Pospiszyl, Kazimierz. Psychologiczna analiza wadliwych postaw społecznych młodzieży. Warszawa: Państwowe Wydawnictwo Naukowe, 1973.

Pospiszyl, Kazimierz, Żabczyńska, Ewa. Psychologia dziecka niedostosowanego społecznie. Warszawa: Państwowe Wydawnictwo Naukowe, 1985.

Pytka, Lesław. „Narodziny i rozwój polskiej pedagogiki resocjalizacyjnej”. Student niepełnosprawny. Szkice i rozprawy 1, 8 (2008).

Spionek, Halina. Zaburzenia psychoruchowe rozwoju dziecka. Warszawa: Państwowe Wydawnictwo Naukowe, 1965.

Spionek, Halina. Zaburzenia rozwoju uczniów a niepowodzenia szkolne. Warszawa: Państwowe Wydawnictwo Naukowe, 1975.

Staineer, George. „Rozumienie jako przekład”. W: Po wieży Babel. Problemy języka i przekładu. Kraków: Universitas, 2000.

Urban, Bronisław. Zaburzenia w zachowaniu i przestępczość młodzieży. Kraków: Wydawnictwo Uniwersytetu Jagiellońskiego, 2000.

Volkmann-Raue, Sibylle, Lück, Helmut E. Najwybitniejsze kobiety w psychologii XX wieku. Gdańsk, Wydawnictwo GWP, 2015.

Wolańczyk, Tomasz, Komender, Jadwiga, Błachno, Magdalena, Bryńska, Anita, Brzozowska, Agata, Ciupak, Marian, Jagielska, Gabriela i in. Zaburzenia emocjonalne i behawioralne u dzieci, red. Helena Baran-Furga. Warszawa: Wydawnictwo Lekarskie PZWL, 2015. 